\title{
Constraints in Using Internet and Social Media as Perceived by Farmers in Karnal District of Haryana, India
}

\author{
N.P. Darshan ${ }^{1 *}$ and B.S. Meena ${ }^{2}$ \\ ${ }^{1}$ Agricultural Extension Division, PJTSAU, Hyderabad-500030, Telangana, India \\ ${ }^{2}$ Dairy Extension Division, National Dairy Research Institute, Karnal-132001, Haryana, India \\ *Corresponding author
}

\section{A B S T R A C T}

\begin{tabular}{|l|}
\hline K e y w o r d s \\
$\begin{array}{l}\text { Farmers, Social } \\
\text { media, Constraints, } \\
\text { Karnal. }\end{array}$ \\
\hline Article Info \\
\hline $\begin{array}{l}\text { Accepted: } \\
\text { 14 September } 2017 \\
\text { Available Online: } \\
\text { 10 October } 2017\end{array}$ \\
\hline
\end{tabular}

Keywords

Farmers, Social media, Constraints, Karnal.

rticle Info

Accepted:

Available Online:

\section{Introduction}

Information is critical in agricultural development because it is a tool for communication between stakeholders and serves as a channel for assessing trends and shaping decisions (Kalusopa, 2005).

Farming requires information and technical expertise hence the need for extension services however, due to various factors extension services are not readily available to all farmers. A consensus exists that extension services, if functioning effectively, improve agricultural productivity by providing farmers with information that helps them to optimize their use of limited resources (Muyanga and Jayne, 2006).
Globalization and technological change processes that have accelerated in tandem over the past years have created a new global economy powered by technology, fueled by information and driven by knowledge. Agriculture sector is also witnessing radical changes and challenges at national and global level. The slow growth observed in the agriculture sector is causing concerns for the future food and nutritional security of the country. The number of clients who need to be covered by extension services is large, and the cost of reaching them is high. Adding to this challenge, farmers' information needs vary even within a given geographical area because of variations in soil, elevation, 
microclimate, and farmers' means enterprises and capabilities.

The goals of agricultural extension includes transferring information from the global knowledge base and from local research to farmers, enabling them to clarify their own goals and possibilities, educating them on how to make better decisions, and stimulating desirable agricultural development (Van den Ban and Hawkins, 1996). Investments in extension services have the potential to improve agricultural productivity and increase farmers' incomes, especially in developing economies, where more than 90.00 per cent of the world's nearly 1 million extension personnel are located. Yet the impact of extension on farm performance is varied, reflecting differences in how extension services are delivered and in the circumstances of service recipients.

Estimates indicated that 60.00 per cent of farmers do not access any source of information for advanced agricultural technologies resulting in huge adoption gap (NSSO, 2005). In India, there are about 120 million farm holdings and the number is growing year by year. At least to provide one village extension personnel for 800-1000 farm families, the requirement of field level extension personnel is estimated to be about 1300000-1500000, against which the present availability is only about 100000 personnel (PC, GOI, 2007).

The emerging challenges and opportunities call for a paradigm shift in the innovation driven agricultural research system to connect inventions with all the stakeholders in the entire food supply chain. Social media and internet are embracing almost all the sectors of life. In agriculture there is a need to reach each and every farmer and provide them the updated information. Communities of social media are open networks where everyone (i.e. clients, users, members) has an opportunity to contribute their ideas and to support mass innovation with one-to-one, one-to-many, and many-to-many interactions (Ashley et al., 2009).

Despite the increasing penetration and influence of internet and social media, farmers abstain from using it due to various constraints. So keeping these points in mind the study was mainly focused to reveal the constraints associated with use of internet and social media by the farmers of Karnal district.

\section{Materials and Methods}

\section{Description of study area}

The study was conducted in Karnal district of Haryana. Karnal, 'the city of Daanvir Karan' was formed as a District on November1, 1966. It is $123 \mathrm{~km}$ from Delhi on the National Highway NH1, (called the GT Road), and 126 $\mathrm{km}$ from Chandigarh. It lies between 29 09'50" and 29 50' North latitude and 76 31' $15^{\prime \prime}$ and 77 12'45" East longitude, its height from sea level is around 240 meters. The district was purposively selected as it has contributed extensively to the green revolution and the socio economic status and literacy level of the respondents was good.

\section{Sampling technique}

Since the distribution of the social media users in the district is unknown whosoever come in contact with ICAR and other agricultural institutes/ departments were selected (most of the contacts were gathered from the institutes). The list of names was gathered from KVKs, ICAR institutes located in Karnal and sampled randomly. A total of 40 farm households constituted the sample size. A structured, pre-tested semi-structured interview schedule was developed for collecting data from the respondents 
according to the objective of the study. Data were collected from the respondents by conducting personal interview method. Statistical tools like frequency, percentage and weighted mean score were used for analysis of the data.

\section{Results and Discussion}

With respect to the constraints faced by the farmers, it was observed from the Table 1 that inadequate service from the network providers (15.33) was the foremost constraint in using the social media.

This was due improper network coverage and inadequate speed services.
Difficulty to find relevant information (15) was the second most serious constraint. The reason for this was due to large number of sources. Inadequate technical knowledge/ skill of using internet and social media tools (13.66) was the third constraint as the majority of farmers were not trained on how to use particular tool.

Unsuitable and incomprehensible information (13.50) was a constraint for the farmers as most of the information was in English language and contain lots of technical words. Inadequate response/feedback from the end user (12.83) was one of the constraints. Farmers felt that lack of reciprocal interaction discourages them from using media tools.

Table.1 Constraints faced by the farmers in using internet and social media

\begin{tabular}{|l|c|c|c|c|}
\hline \multicolumn{1}{|c|}{ Category } & Most serious & Serious & $\begin{array}{c}\text { Least } \\
\text { serious }\end{array}$ & WMS \\
\hline $\begin{array}{l}\text { Inadequate service (network coverage, } \\
\text { speed) }\end{array}$ & $\begin{array}{c}23 \\
(57.50)\end{array}$ & $\begin{array}{c}6 \\
(15.00)\end{array}$ & $\begin{array}{c}11 \\
(27.50)\end{array}$ & 15.33 \\
\hline $\begin{array}{l}\text { Difficulty to find relevant information } \\
\text { (due to large number of sources) }\end{array}$ & $\begin{array}{c}14 \\
(35.00)\end{array}$ & $\begin{array}{c}20 \\
(50.00)\end{array}$ & $8(20.00)$ & 15.00 \\
\hline Inadequate technical knowledge/ skill & 9 & 24 & $7(17.50)$ & 13.66 \\
\hline $\begin{array}{l}\text { Unsuitable and incomprehensible } \\
\text { information }\end{array}$ & $\begin{array}{c}14 \\
(60.00)\end{array}$ & 13 & 13 & 13.50 \\
\hline Inadequate response & $\begin{array}{c}11 \\
(27.50)\end{array}$ & $\begin{array}{c}15 \\
(37.50)\end{array}$ & $\begin{array}{c}14 \\
(35.00)\end{array}$ & 12.83 \\
\hline $\begin{array}{l}\text { Inadequacy of tools (smart phones, } \\
\text { laptops) }\end{array}$ & $\begin{array}{c}9 \\
(22.50)\end{array}$ & $(45.00)$ & $(32.50)$ & 12.66 \\
\hline
\end{tabular}

Figures in the parenthesis indicate per cent WMS - Weighted mean score

Inadequacy of tools (12.66) was a constraint for the farmers as they felt that without proper gadgets like smartphones and/or computers/laptops they were unable to access internet and social media tools.

A critical analysis of constraints as perceived by farmers in using social media revealed that majority of farmers felt improper service of network provider, difficulty to find relevant information, inadequate skill in using tools, unsuitable and incomprehensible information etc. were the constraints as perceived by the farmers. In the light of farmers moving away from agriculture there is a need to attract and retain them in agriculture sector. In this context internet and social media forms good media tools and there is a need to address the issues with respect to the use of internet and social media. It is an important obligation on 
the part of extension system (both public and private) to collaborate services of Telecom regulatory authority of India (TRAI) and ICT service providers to continue giving support mechanisms to internet and social media userfarmers.

\section{Acknowledgments}

I would like to thank my chairperson Dr. B. S. Meena for guiding me throughout my research study. I thank Dairy Extension Division of National Dairy Research Institute Karnal for allowing me to pursue my research study. I thank all the farmers who gave suitable information for the research study.

\section{References}

Ashley, H., Corbett, J., Jones, D., Garside, B. and Rambaldi, G. 2009. Change at Hand: Web 2.0 for Development. Participatory Learning and Action, 59: 8-20.

Darshan N. P., 2015. Exploring the potential use of social media in communicating agricultural information in Haryana. M. Sc. Thesis. National Dairy Research Institute. Karnal (India).
Kalusopa, T., 2005. The Challenges of Utilising Information and Communication Technologies (ICT's) for the small scale farmer in Zambian. IN: Library Tech, 23(3)414-424, www.emeraldinsight.com/07378831.htm. Retrieved on 8th January, 2011.

Muyanga, M., and Jayne, T. S. 2006. Agricultural Extension in Kenya: Practice Policy and Lessons. Practice and Policy Lessons. Tegemeo Institute of Agriculture and Policy Development, Egerton University.

NSSO, 2005. Access to modern technology for farming, situation assessment survey of farmers, 59th Round, Report No. 499, National Sample Survey Organization (NSSO), Ministry of Statistics and Program Implementation, Government of India, New Delhi.

PC, GoI, 2007. Recommendations of working group on agricultural extension for formulation of eleventh five year plan (2007-12), Planning Commission, Government of India, New Delhi.

Van Den Ban, A. W., and H. S. Hawkins 1996. Agricultural extension. Oxford [etc.], Blackwell.

\section{How to cite this article:}

Darshan, N.P. and Meena, B.S. 2017. Constraints in Using Internet and Social Media as Perceived by Farmers in Karnal District of Haryana, India. Int.J.Curr.Microbiol.App.Sci. 6(10): 1465-1468. doi: https://doi.org/10.20546/ijcmas.2017.610.173 